РОЗДІЛ ІІІ. ПРОБЛЕМИ ІСТОРІЇ ПЕДАГОГІКИ

удк 373.5.091.33:811.11](477.85)"1918/ 1940"

Ольга Гоменюк

Тернопільський національний педагогічний

університет імені Володимира Гнатюка

ORCID ID 0000-0001-5398-5593

DOI 10.24139/2312-5993/2020.03-04/194-206

\title{
МЕТОДОЛОГІЧНІ ЗАСАДИ РОЗВИТКУ МЕТОДИКИ НАВЧАННЯ ГЕРМАНСЬКИХ МОВ НА БУКОВИНІ (ПЕРША ПОЛОВИНА ХХ СТ.)
}

у статті обгрунтовано методологічні засади дослідження проблеми розвитку методики навчання германських мов на Буковині (першої половини XX cm.). Визначено, що вибір методологічного інструментарію зумовлений міждисциплінарним характером дослідження та базується на загальнонауковому й конкретно-науковому рівнях. Виокремлені рівні наукового пізнання уможливили грунтовне вивчення проблеми з урахуванням особливостей методики навчання германських мов на Буковині в зазначений хронологічний період.

Ключові слова: методологічні засади, методика навчання германських мов загальнонауковий рівень, конкретно-науковий рівень, міждисциплінарність, методологічні підходи, методи, принципи, історико-педагогічний процес.

Постановка проблеми. Характерними рисами наукових досліджень $\epsilon$ цілеспрямованість, формулювання та розв'язання конкретних наукових завдань, пошук бібліографічних джерел та добір фактичного матеріалу, відкриття невідомих явищ і закономірностей, введення нових гіпотез та ідей, вирішення й обґрунтування розглянутих питань, систематизація нових знань, аргументованість, репрезентація одержаних результатів. 3 метою вирішення поставлених завдань в історико-педагогічних працях, важливо визначити методологічні підходи, принципи і методи, що утворюють методологічну систему дослідження розвитку методики навчання германських мов у різних типах шкіл Буковини в першій половині XX ст.

Аналіз актуальних досліджень. У наш час багато науковців звертаються до вивчення питань, пов'язаних із формуванням системи методологічного апарату в історико-педагогічних дослідженнях. Проблемам методологічного забезпечення наукових досліджень присвячено праці видатних педагогів-науковців, а саме: О. В. Адаменко, Л. Д. Березівської, Л.Ц. Ваховського, С.У.Гончаренко, Н. М. Гупана, І. А. Зязюна, О. С. Падалки, С. О. Сисоєвої, О.В.Сухомлинської, Є. М. Хрикова та ін. Однак, методологічні основи розвитку методики навчання германських мов на Буковині в першій половині XX ст. не були предметом спеціального наукового дослідження. 
Мета статті полягає у визначенні й обґрунтуванні методологічного інструментарію дослідження проблеми розвитку методики навчання германських мов на Буковині в першій половині XX ст.

Методи дослідження. Для реалізації поставленої мети використано аналіз, порівняння, систематизацію та узагальнення спеціальної науковопедагогічної літератури, що уможливило виокремлення методологічних засад розвитку методики навчання германських мов у різних типах шкіл буковинського краю в першій половині XX ст.

Виклад основного матеріалу. Необхідною умовою розвитку будьякої наукової діяльності $€$ послідовність виконання та оформлення результатів наукового дослідження на основі методологічних засад.

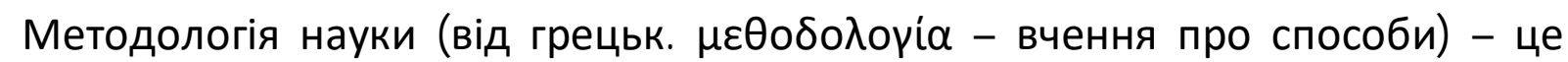
система методологічних і методичних принципів та прийомів, операцій і форм побудови наукового знання (Зацерковний та ін., 2017, с. 72).

Методологія вивчає всі компоненти наукової пізнавальної діяльності в їх взаємозв'язку. Ії̈ завдання полягають у дослідженні механізмів, можливостей і перспектив формування нового знання в їх залежності від досліджуваного об'єкта, історично сформованих пізнавальних засобів, цілей і установок суб'єкта пізнання (Пунченко, 2014, с. 29).

Функції методології полягають у наступному:

- визначає способи здобуття наукових знань, що відображають динамічні процеси та явища;

- спрямовує, передбачає особливий шлях, на якому досягається певна науково-дослідницька мета;

- забезпечує всебічність отримання інформації щодо процесу чи явища, що вивчається;

- допомагає введенню нової інформації до фонду теорії науки у вигляді нових понять, категорій, законів, гіпотез, ідей, теорій;

- забезпечує уточнення, збагачення, систематизацію термінів і понять у науці;

- створює систему наукової інформації, яка базується на об'єктивних фактах, і логіко-аналітичний інструмент наукового пізнання;

- організує використання нових знань у практичній діяльності (Зацерковний та ін., 2017, с. 72).

Отже, методологія забезпечує процес наукового пізнання методами, прийомами, формами і способами науково-дослідницької діяльності. Методологічне обґрунтування окреслює загальний підхід до дослідження, розкриваючи конкретніші твердження. Вони виступають методологічними орієнтирами, що розвивають систему наукового знання.

Необхідно зазначити, що методологічний апарат нашого дослідження зумовлений міждисциплінарним напрямком роботи. Як зазначає український історик І. Рассоха, методи міждисциплінарного дослідження являють собою 
сукупність низки синтетичних, інтегративних способів, які виникли в результаті сполучення елементів різних рівнів методології, спрямованих переважно на стики наукових дисциплін. Ці методи обумовлені поглибленням взаємозв'язків наук, які призводять до того, що результати, прийоми і методи однієї науки широко використовуються в інших (Рассоха, 2011, с. 51). Тому міждисциплінарний характер історії методики навчання германських мов розглядаємо як соціально-історичну парадигму ретроспективних методичних досліджень, яка визначає перевагу методологічних зв'язків та закономірностей взаємодії педагогіки, психології, лінгвістики, історії України та методики навчання германських мов.

Методологічний інструментарій нашого дослідження базується на загальнонауковому та конкретно-науковому рівнях. Підходам кожного рівня притаманна власна специфіка, які безпосередньо не застосовуються ізольовано, а лише в поєднанні з іншими.

До загальнонаукового рівня методології, який застосовується в більшості наукових досліджень, ми відносимо системний, синергетичний i парадигмальний підходи. На нашу думку, саме вони дадуть змогу комплексно розглянути історико-соціальні та освітньо-організаційні передумови, самоорганізацію процесу навчання, у тому числі учасників педагогічного процесу, а також уможливлять виділення багатоваріантності й альтернативності шляхів подальшого розвитку методики навчання германських мов.

Системний підхід - це напрям у спеціальній методології науки, завданням якого $€$ розробка методів дослідження й конструювання складних за організацією об'єктів як систем. Системний підхід у педагогіці спрямований на розкриття цілісності педагогічних об'єктів, виявлення в них різноманітних типів зв'язків та зведення їх у єдину теоретичну картину (Гончаренко, 1997, с. 305).

Сутність системного підходу полягає в тому, що відносно самостійні компоненти розглядаються не ізольовано, а в їх взаємозв'язку та розвитку. Він дозволяє виявити інтегративні системні властивості і якісні характеристики складових елементів системи. Предметний, функціональний та історичний аспекти системного підходу потребують реалізації в єдності таких принципів дослідження, як історизм, конкретність, урахування всебічних зв'язків і розвитку (Загальні підходи i принципи наукового дослідження).

Кожну конкретну науку, об'єкт чи діяльність можна вивчати як певну систему, що складається із взаємопов'язаних елементів, компонентів, підсистем, а також визначених цілей, функцій, структури та складу. Адже системою називають сукупність об'єктів із їх відносинами і зв'язками, що володіє такими ознаками: цілісністю (певною незалежністю системи від зовнішнього середовища і від інших систем), зв'язністю (наявністю зв'язків, 
що дозволяють за допомогою переходів по них від елемента до елемента з'єднувати декілька будь-яких елементів системи), функцією (наявністю цілей, що не $є$ простою сумою цілей елементів, що належать системі) (Гуменюк та Корець, 2014, с. 63).

Системний підхід дає змогу досліджувати будь-яке історикопедагогічне явище як системне утворення, окреслюючи ознаки системи: наявність сукупних елементів, кожен із яких $€$ мінімальною одиницею, що має межу подільності в рамках цієї системи; наявність певних зв'язків і відношень між елементами системи; функціонування системи та ії властивості зумовлені її структурною специфікою; наявність у системі певного рівня цілісності, тобто внутрішніх інтегративних якостей, що виникають унаслідок взаємодії їі елементів; наявність спільної структури, яка об'єднує всі елементи системи й забезпечує повноту названих елементів та узгодженість усіх їхніх функцій; наявність зв'язків з іншими системами; спрямованість системи на вирішення якоїсь проблеми (Кузнецова, 2001, с. 57).

Навчання германських мов у закладах загальної середньої освіти на Буковині визначаємо як систему, функціонування якої зумовлено багатьма чинниками. Основними з них виступають характер соціального замовлення на певному етапі розвитку суспільства, підходи, принципи, мета навчання й виховання та зміст навчання.

Навчання германських мов - спеціально організований процес, у ході якого в результаті взаємодії вчителя та учня здійснюється засвоєння та відтворення іншомовного мовленнєвого досвіду відповідно до поставленої мети (Методика навчання іноземних мов і культур, 2013, с. 29). 3 огляду на цільове призначення методики навчання германських мов на Буковині в зазначений хронологічний період, виділимо такі структурні компоненти системи:

1. Мета навчання германських мов: передбачення кінцевих результатів педагогічної діяльності.

2. Зміст навчання германських мов: обсяг навчальної інформації, яку учень повинен засвоїти у процесі навчання.

3. Завдання навчання германських мов: засвоєння знань 3 германських мов та формування вмінь практично застосовувати ці знання в повсякденному житті чи для досягнення професійних цілей.

4. Засоби навчання германських мов: об'єкти матеріальної та духовної культури, які використовують у навчально-виховному процесі і завдяки яким реалізується мета навчання германських мов.

5. Форми навчання германських мов: шкільні заняття, виконання домашніх завдань, відвідування гуртків, товариств.

6. Методи навчання германських мов: способи взаємопов'язаної діяльності педагога та учнів, які спрямовані на вирішення завдань процесу навчання. 
7. Результат навчання германських мов: володіння IM на відповідному рівні.

Структурні елементи системи взаємопов'язані між собою та взаємодіють із зовнішнім середовищем, формуючи та проявляючи свої властивості, однак, зберігаючи при цьому стійкість свого функціонування. Одним із системотвірних факторів $€$ мета, яка виступає головним призначенням системи. Структурні компоненти системи навчання германських мов взаємодіють під впливом зовнішніх та внутрішніх чинників, створених людиною (науково-методичні засади, нормативноправова база). Результат виступає фактором впорядкованості в системі навчання германських мов, оскільки має вплив на всю систему. Разом із тим, організація навчального процесу впливає на його результати і створює умови для досягнення цілей навчання.

Роль штучно сформованого зовнішнього середовища в системі навчання виконує школа, яка утворена за замовленням суспільства. Згідно $з$ соціально-економічними умовами та з урахуванням розвитку і потреб учнів, формулюється «соціальне замовлення» для школи, що спрямоване на виховання певного типу особистості. Оформлення визначеної суспільством мети здійснюється за допомогою нормативно-правових документів і законодавчих актів. Мета навчання певною мірою визначає відповідний зміст навчання взагалі, навчання германських мов зокрема. Структуру змісту навчання формують певні компоненти, які пов'язані з відбором завдань, що реалізується за допомогою різноманітних засобів та форм.

Ураховуючи складність та багаторівневість структури системи, визначається кількість рівнів ієрархії організації та управління системою. Для системи навчання германських мов на Буковині визначено розподіл регіональних освітніх систем управління за такими рівнями: 1) Міністерство віровизнань і освіти Румунії; 2) XIV окружний шкільний інспекторат Буковини; 3) Чернівецький повітовий шкільний ревізорат; 4) школа.

Отже, застосування системного підходу допомогло обґрунтувати сутність поняття «методика навчання германських мов» та окреслити тематичний словник нашого дослідження, який включає понятт, що належать до організаційно-педагогічного підґрунтя навчання германських мов, а саме: «система навчання германських мов», «нормативно-правова база навчання германських мов», «науково-методичне забезпечення навчання германських мов», «організація навчання германських мов», «зміст навчання германських мов», «результат навчання германських мов».

Сутність синергетичного підходу полягає в дослідженні процесів самоорганізації та становлення нових упорядкованих структур. Він реалізується в дослідженні систем різної природи: фізичних, біологічних, соціальних, когнітивних, інформаційних, екологічних тощо (Зацерковний та iн., 2017, с. 59). 
Предметом синергетики $€$ механізми спонтанного формування i збереження складних систем, зокрема тих, які перебувають у стані стійкої нерівноваги із зовнішнім середовищем. У сферу ії вивчення потрапляють нелінійні ефекти еволюції систем будь-якого типу, кризи й біфуркації нестійкої фази існування, які передбачають множинність сценаріїв подальшого розвитку (Зацерковний та ін., 2017, с. 59-60).

Біфуркаційні процеси - це стан системи, який визначає подальший ії розвиток i $\epsilon$ наслідком неврівноважених процесів всередині системи, викликаних нарощуванням флуктуацій, згасити які система самостійно не здатна. Це явище породжує хаос або дисипативність, що визначається як особливий стан структури системи, відхилення від рівноваги. У так званій точці біфуркації, викликаної флуктуаціями, система випробовується на стійкість. Точка біфуркації являє собою переломний, критичний момент у розвитку системи, у якому вона здійснює вибір шляху (Вознюк, 2012, с. 92). Синергетика, намагаючись відтворити загальні принципи процесів самоорганізації складних систем, у тому числі й соціальних, формує новий стиль синергетичного мислення, провідними рисами якого $€$ імовірнісне бачення світу, зосередження уваги на нелінійності, але водночас цільності і стійкості соціальних структур, системному ефекті їх додавання, наслідком дії якого є пряма залежність поведінки елементів, що утворюють систему від особливостей їх субординаційної, координаційної й автономної взаємодії (Панфілов та Романова, 2019, с. 72).

О. Вознюк вважає, що синергетика постає новим міждисциплінарним напрямом, своєрідною міждисциплінарною рефлексією, предметом якої $є$ механізми самоорганізації у природних, соціальних, педагогічних системах, що постають відкритими сутностями. У сфері педагогічної думки останнім часом набуває розвитку педагогічна концепція синергізму, а методологія синергетики починає активно впроваджуватися у сферу педагогіки, що позначилось на розробці синергетичного підходу до аналізу освітніх реалій та формуванні педагогічної синергетики (Вознюк, 2012, с. 214).

Використання в дослідженні синергетичного підходу реалізується в процесі самостворення й саморозвитку біфуркацій у методиці навчання іноземних мов на Буковині, які позначилися на вивченні германських мов (німецької та англійської мов).

Парадигмальний підхід в історії педагогіки - ґенеза теоретичних положень, що дає змогу науковцям та практикам виявити, сформулювати й описати цілісні моделі освіти (Рупташ, 2014, с. 23). Парадигма - це сукупність знань, переконань, припущень, цінностей, методів і прийомів пізнання, світоглядний каркас сприйняття дійсності, спільний для певної групи суб'єктів. У межах нашого дослідження для кращого усвідомлення використання парадигмального підходу в методиці навчання германських мов вважаємо за необхідне розглянути принципи парадигмального підходу, до яких належать: 
1. Принцип системно-цілісної будови зрілої парадигми, що вимагає формування іiї «дисциплінарної матриці» - компонентного складу 3 чотирьох нормативних підсистем (включаючи «зразки», «моделі», «символи» і «цінності»), що зважають на специфіку відповідної галузі науки або сфери соціального життя.

2. Принцип наукової евристичності парадигми, що полягає в ї̈ здатності допомагати в рішенні нових пізнавальних проблем.

3. Принцип домінування однієї парадигми, що припускає наявність пануючого теоретико-нормативного зразка, відповідно до якого будуються дослідження.

4. Принцип часової обмеженості існування парадигми, що виражає певну тривалість ії домінування, у межах конкретного історичного періоду.

5. Принцип якісної несумірності парадигм, що означає, що кожна нова парадигма $\epsilon$ іншим баченням світу в порівнянні з попередньою (Утюж, 2014, с. 124).

Використання принципів парадигмального підходу в дослідженні дозволяє визначити закономірні етапи трансформації якісних змін у методиці навчання германських мов.

Вивчення історико-педагогічного процесу засвідчує, що науковопедагогічне знання традиційно розвивалося через безперервне висунення нових гіпотез і створення таких концепцій, у яких та чи інша проблема знаходила поглиблене й усебічне висвітлення. Тим самим не відбувалося спростування загальної ідеї, вираженої у формі гіпотези, концепції й теорії, а зазнавала критики лише та конкретна форма її вияву, яку мала ця гіпотеза, концепція і теорія в кожний конкретний час. Розвитку педагогічного знання властивий динамізм, що вимагає поліпарадигмального підходу до вивчення історико-педагогічного процесу (Коваленко, 2012, с. 30). Поліпарадигмальний підхід передбачає історіографічне висвітлення логіки розвитку історико-педагогічної проблематики, процес взаємодії різних парадигм та механізм зміни домінувальної парадигми в конкретних історичних умовах (Гупан, 2002, с. 53).

Дослідження особливостей розвитку методики навчання германських мов на Буковині здійснювалося в загальній парадигмі методики навчання іноземних мов в краї, обґрунтовуючи передумови становлення методики навчання германських мов, що нерозривно пов'язане зі здобутками історії педагогіки та історичної науки.

Міждисциплінарність у нашому дослідженні, застосування методологічного інструментарію в історичному ракурсі методики навчання германських мов зумовлює застосування комплексу конкретно-наукових підходів $i$ методів, які представлені регіональним, хронологічним підходами, методами критичного аналізу літературних джерел, вивчення та узагальнення позитивного досвіду роботи вчителів німецької та англійської мови. 
На думку Я. Верменич, історична регіоналістика являє собою поле ретроспективного дослідження процесів життєдіяльності людських спільнот і комунікативних зв'язків у межах регіонів, що історично склалися. Розвиваючи традиції «землеописань» в історіографії, нині вона дістала можливість виходу на новий рівень міждисциплінарного синтезу - 3 аналізом «семіотики культурного простору», регіональної самосвідомості, асиміляційних і трансформаційних процесів (Верменич, 2014, с. 14). Таким чином, регіоналістика, як міждисциплінарний науковий напрям, займається процесами, що мали значний вплив на адміністративнотериторіальні, національно-етнічні та освітньо-організаційні чинники розвитку методики навчання германських мов Буковини.

Використання регіонального підходу в нашому дослідженні дає змогу визначити особливості становлення та розвитку освіти в буковинському регіоні та розкрити історико-соціальні, територіальні, освітньо-організаційні характеристики Буковини в складі Румунії (1918-1940рр.).

Для нашого дослідження досить важливим $€$ хронологічний підхід, який дає можливість висвітлити історичний матеріал у хронологічній послідовності, а також проаналізувати закономірності розвитку історичного явища на всіх етапах. Визначення хронологічних меж дослідження $\epsilon$ істотною складовою будь-якої історико-педагогічної розвідки. Питання періодизації постають перед кожним дослідником, який розпочинає свою роботу. Насамперед, хронологічний вимір залежить від проблеми дослідження, їі масштабності (Сухомлинська, 2005, с. 45). Хронологічний підхід використовуємо в ході розробки періодизації методики навчання германських мов на Буковині, опису навчальних програм та підручників, підходів, принципів, методів навчання німецької та англійської мови.

Серед сучасних методів дослідження особливе місце відводимо методу критичного аналізу літературних джерел і методу вивчення й узагальнення позитивного досвіду роботи вчителів, які дають змогу розкрити сутність об'єкта дослідження.

Метод критичного аналізу літературних джерел дозволив простудіювати навчальні програми, підручники з німецької і англійської мови та публікації в періодичних виданнях того часу, що уможливило виокремлення способів реалізації методів навчання германських мов на Буковині (прямого і змішаного методів).

Вивчення та узагальнення позитивного досвіду роботи вчителів дало можливість скласти уявлення про особливості процесу навчання германських мов, визначити прийоми, які використовували в межах реалізації методів навчання германських мов на Буковині.

На конкретно-науковому рівні ми розглядаємо методи, що використовують в історичних дослідженнях: історико-структурний, 
історико-генетичний, історико-порівняльний, історико-системний і метод термінологічного аналізу.

Історико-структурний метод (розподіл явищ та процесів минулого на складові) зумовив структуризацію дослідження, яке базується на встановленні передумов розвитку методики навчання германських мов на Буковині в першій половині XX ст., дослідженні навчальних програм та планів, детальному аналізі підручників з німецької і англійської мови, визначенні особливостей реалізації методів навчання германських мов на Буковині, а також виділенні етапів розвитку методики навчання германських мов на Буковині в досліджуваний період.

Історико-генетичний метод полягає в послідовному розкритті властивостей, функцій і змін досліджуваної реальності у процесі ії історичного розвитку, що дозволяє повною мірою наблизитися до відтворення реальної історії об'єкта. За логічною сутністю історикогенетичний метод $€$ аналітично-індуктивним, а за формою вираження інформації про досліджувану реальність - описовим. Історико-генетичний метод дає можливість виявити причинно-наслідкові зв'язки й закономірності історичного розвитку, охарактеризувати історичні події й особистості в їхній індивідуальності та образності (Драч, 2014, с. 6-7).

Історико-порівняльний метод - сукупність пізнавальних засобів, процедур, які дозволяють виявити схожість і відмінність між явищами, що вивчаються, визначити їхню генетичну спорідненість (зв'язок за походженням), загальне й специфічне в їхньому розвитку (Зацерковний та ін., 2017, с. 57). Об'єктивною основою для порівнянь $€$ те, що суспільно-історичний розвиток - це повторюваний, внутрішньо обумовлений, закономірний процес. Історико-порівняльний метод дає можливість розкривати сутність досліджуваних явищ за подібністю й відмінністю їхніх властивостей, а також здійснювати порівняння в просторі й часі (Драч, 2014, с. 7).

у нашому дослідженні історико-порівняльний метод дав змогу порівняти особливості методики навчання германських мов на Буковині на різних етапах розвитку. Реконструкція подій та явищ минулого, формулювання висновків на базі порівняння й зіставлення дали змогу розробити періодизацію методики навчання германських мов, типологію змістових форм, установити змістово-процесуальну основу методики навчання германських мов.

Історико-системний метод обумовлений поглибленням історичних аспектів освітологічних досліджень як із погляду цілісного охоплення соціальної реальності, так і з погляду розкриття внутрішніх механізмів функціонування й розвитку різних освітніх систем в різні історичні епохи. Об'єктивна основа системного підходу й методу наукового пізнання єдність у суспільно-історичному розвитку одиничного (індивідуального), особливого й загального. Конкретно ця єдність виявляється в суспільно- 
історичних системах різного рівня. Зокрема, функціонування й розвиток освітніх систем включає й синтезує ті основні компоненти, 3 яких складається соціальна реальність, а саме індивідуальні і неповторні події, історичні ситуації та процеси. За внутрішнім змістом ці компоненти являють собою конкретну й цілеспрямовану діяльність людей і нерозривно взаємопов'язані з нею (Драч, 2014, с. 8).

За допомогою історико-системного аналізу нам вдалося сформувати цілісну картину з комплексним урахуванням основних характеристик процесу навчання германських мов на Буковині в першій половині XX ст.

Ураховуючи принципи історико-системного підходу, методику навчання германських мов як систему розглядаємо в межах загальної середньої освіти Буковини, на яку мали вплив історико-соціальні, політичні та економічні процеси. Разом із тим в основі дослідження закладено, що сутність змісту та організації методики навчання германських мов залежить від системи взаємозв'язків: урядової політики в галузі освіти, суспільної думки, розвитку педагогічної науки та методики навчання IM в Румунії загалом і на Буковині зокрема. Відмітимо, що в нашому дослідженні розглядаємо лише зміни, які відбулися в методиці навчання германських мов з огляду на зміни шкільної системи освіти на Буковині на початку XX століття.

Метод термінологічного аналізу дав змогу розтлумачити деякі терміни, пов'язані з предметом дослідження: «навчальна програма», «підручник», «підхід», «принцип», «метод» тощо. Загальновідомо, що для пояснення педагогічних та методичних термінів пропонуються кілька тлумачень. 3 метою уникнення невизначеності формулювань у процесі розгляду певних явищ дослідження важливо було пояснити значення відповідних термінів.

Висновки. Отже, аналіз дослідження розвитку методики навчання германських мов на Буковині в першій половині XX ст. здійснювався на підґрунті дворівневого методологічного апарату, який забезпечив застосування певних підходів, методів, формулювання принципів до опису наукового дослідження й пошуку конструктивних оптимальних рішень досліджуваної проблеми. Міждисциплінарність у контексті нашого дослідження зумовила вибір методологічного інструментарію. Загальнонауковий та конкретно-науковий рівні уможливили ґрунтовне вивчення проблеми з урахуванням особливостей методики навчання германських мов на Буковині в зазначений хронологічний період.

Перспективи подальших наукових досліджень вбачаємо у визначенні та обґрунтуванні етапів розвитку методики навчання германських мов на Буковині (1918-1940рр.).

\section{ЛІТЕРАТУРА}

Верменич, Я. В. (2001). Історична регіоналістика в Україні. Український історичний журнал, 6, 3-26 (Vermenych, Ya. V. (2001). Historical regionalism in Ukraine. Ukrainian Historical J ournal, 6, 3-26). 
Верменич, Я. В. (2014). Історична регіоналістика. Київ: Інститут історії України НАН України (Vermenych, Үa. V. (2014). Historical regionalism. Kyiv: Institute of History of Ukraine, National Academy of Sciences of Ukraine).

Вознюк, О. В. (2012). Педагогічна синергетика: генеза, теорія і практика. Житомир: Вид-во ждУ імені Івана Франка (Vozniuk, O. V. (2012). Pedagogical synergetics: genesis, theory and practice. Zhytomyr: Publishing house of Zhytomyr Ivan Franko State University).

Гончаренко, С. У. (1997). Український педагогічний словник. Київ: Либідь (Honcharenko, S. U. (1997). Ukrainian Pedagogical Dictionary. Kyiv: Lybid).

Гуменюк, Т. Б., Корець, М. С. (2014). Системний підхід як складова освітньої інноватики. Наука і освіma, 7, 63-67 (Humeniuk, T. B., Korets, M. S. (2014). Systems approach as a component of educational innovation. Science and education, 7, 63-67).

Гупан, Н. М. (2002). Українська історіографрія історії педагогіки. Київ: А.П.Н. (Hupan, N. M. (2002). Ukrainian historiography of the history of pedagogy. Kyiv: A.P.N.).

Драч, О. О. (2014). Сучасні історико-освітні дослідження: традиції та новації методології. Вісник Черкаського університету. Серія: «Історичні науки», 9 (302), 5-11 (Drach, 0. 0. (2014). Modern historical educational research: methodological traditions and innovations. Bulletin of Cherkasy University. Series: "Historical Sciences", 9 (302), 133-136).

загальні підходи і принципи наукового дослідження. Режим доступу: https://studfile.net/preview/6441043/page:2/ (General approaches and principles of scientific research. Retrieved from: https://studfile.net/preview/6441043/page:2/).

Зацерковний, В. І., Тішаєв, І. В., Демидов, В. К. (2017). Методологія наукових досліджень. Ніжин: НДУ ім. М. Гоголя (Zatserkovnyi, V. I., Tishaiev, I. V., Demydov, V. K. (2017). Research methodology. Nizhyn: Nizhyn M ykola Gogol State University).

Коваленко, Є. І. (2012). Методологічна функція історії педагогіки у становленні майбутнього педагога. Наукові записки Ніжинського державного університету імені Миколи Гоголя. Психолого-педагогічні науки, 4, 27-35 (Kovalenko, Ye. I. (2012). The methodological function of the history of pedagogy in formation of prospective teachers. Scientific Notes of Nizhyn State University named after M ykola Gogol. Psychological and pedagogical sciences, 4, 27-35).

Кузнецова, А. Г. (2001). Развитие методологии системного подхода в отечественной педагогике. Хабаровск (Kuznetsova, A. H. (2001). Development of a Methodology for a Systems Approach in Domestic Pedagogy. Khabarovsk).

Лабінська, Б. І. (2013). Історичні нариси з методики навчання іноземних мов на західноукраїнських землях (друга половина XIX - перша половина XX cm.). Київ: кнлу (Labinska, В. І. (2013). Historical sketches on the methodology of teaching foreign languages in the Western Ukrainian lands (the second half of the XIX - the first half of the XX century). Kyiv: KNLU).

Ніколаєва, С. Ю., Бігич, О. Б., Бориско, Н. Ф., Борецька, Г. Е. (2013). Методика навчання іноземних мов і культур: теорія і практика. Київ: Ленвіт (Nikolaieva, S. Yu., Bihych, O. B., Borysko, N. F., Boretska, H. E. (2013). M ethods of Teaching Foreign Languages and Cultures: Theories and Practice. Kyiv: Lenvit).

Панфілов, О. Ю., Романова, І. В. (2019). Синергетичний підхід в осмисленні освіти. Вісник Національного юридичного університету імені Ярослава Мудрого, 3 (42), 71-80. DOI: https://doi.org/10.21564/2075-7190.42.170335 (Panfilov, 0. Yu., Romanova, I. V. (2019). Synergetic approach to interpretation of education. Bulletin of the National Law University named after Yaroslav Mudryi, 3 (42), 71-80. DOI: https://doi.org/10.21564/2075-7190.42.170335). 
Пунченко, О. П. (2014). Методологічні новації у сучасному науковому пізнанні. Гуманітарний вісник ЗДІА, 57, 27-37 (Punchenko, О. Р. (2014). Methodological innovations in the modern scientific knowledge. Humanitarian Bulletin of Zaporizhzhia State Engineering Academy, 57, 27-37).

Рассоха, І. М. (2011). Конспект лекцій з навчальної дисципліни «Методологія та організація наукових досліджень». Харків: ХНУМГ (Rassokha, I. М. (2011). Compendium of Lectures on the "Methodology and organization of scientific research". Kharkiv: O. M. Beketov National University of Urban Economy in Kharkiv).

Рупташ, О. В. (2014). Парадигмальний підхід у гуманітарних науках. Нова парадигма, 122, 20-32. Режим доступу: http://nbuv.gov.ua/UJRN/Nopa 20141225 (Ruptash, O. V. (2014). A Paradigm Approach in the Human Sciences. New Paradigm, 122, 20 32. Retrieved from: http://nbuv.gov.ua/UJRN/Nopa_2014_122_5).

Сухомлинська, О. В. (2005). Історико-педагогічне дослідження та його «околиці». Шлях освіти, 4, 43-47 (Sukhomlynska, 0. V. (2005). Historical and pedagogical research and its "surroundings". The way of education, 4, 43-47).

Утюж, І. Г. (2014). Використання парадигмального підходу в освіті. Політологічний вісник, 74, 120-128. Режим доступу: http://nbuv.gov.ua/UJRN/Pv_2014_74_11 (Utiuzh, I. H. (2014). The use of Paradigms approach in Education. Politology bulletin, 74, 120-128. Retrieved from: http://nbuv.gov.ua/UJRN/Pv_2014_74_11).

\section{PEЗЮME}

Гоменюк Ольга. Методологические основы развития методики обучения германских языков на Буковине (первая половина XX ст.).

В статье обоснованы методологические основы исследования проблемы развития методики обучения германских языков на Буковине (первой половины XX в.). Определено, что выбор методологического инструментария обусловлен междисциплинарным характером исследования и базируется на общенаучном и конкретно-научном уровне. Выделенные уровни научного познания позволили основательно изучить проблему с учетом особенностей методики обучения германских языков на Буковине в указанный хронологический период.

Ключевые слова: методологчческие основы, методика обучения германских языков, общенаучный уровень, конкретно-научный уровень, междисциплинарность, методологические подходы, методы, историко-педагогический прочесс.

\section{SUM MARY}

Homeniuk Olha. Methodological fundamentals of the development of Germanic languages teaching methods in Bukovyna (first half of the XX century).

The article deals with the methodological basis of the development of Germanic languages teaching methods in Bukovyna in the first half of the XX century.

Characteristic features of scientific research are formulation and solution of scientific problems, the search of bibliographic sources and selection of factual material, introduction of new hypotheses and ideas, systematization of new knowledge, representation of the results.

The purpose of the article is to define and substantiate the methodological tools for studying the problem of the development of Germanic languages teaching methods in Bukovyna (first half of the XX century).

To achieve this goal, we have chosen the following research methods: analysis, comparison, systematization, and generalization of scientific and pedagogical literature. They allowed us to single out the methodological basis for the development of Germanic languages teaching methods in different types of schools in Bukovyna region (in the first half of the twentieth century). 
It has been used a two-level methodological apparatus for the analysis of the research on the development of Germanic languages teaching methods in Bukovyna in the first half of the twentieth century.

The general scientific level of the methodology includes systems, synergetic, and paradigmatic approaches. In our opinion, they will allow us to consider comprehensively historical, social, educational, organizational preconditions. As a result, we will be able to allocate multivariate and alternative ways of further development of Germanic languages teaching methods.

At the specific scientific level, it has been applied regional, chronological approaches, methods of critical analysis of literary sources, study and generalization of German and English teachers' positive experience.

It has been determined that the choice of methodological tools is based on the interdisciplinary character of the research. Due to the general and specific scientific levels, we have studied the problem thoroughly, taking into account the peculiarities of Germanic languages teaching methods in Bukovyna in the period under investigation. Thus, the applied approaches, methods, principles made it possible to describe the study and to search for constructive solutions to the problem.

Further research prospects include defining and substantiating the stages of the development of Germanic languages teaching methods in Bukovyna in 1918-1940.

Key words methodological fundamentals, Germanic languages teaching methods, general scientific level, specific scientific level, interdisciplinarity, methodological approaches, methods, principles, historical and pedagogical process. 